\title{
2.3 Дослідження проблемних аспектів природокористування для раціоналізації та ефективності його управління
}

Проблеми природокористування, екологічного стану та пов'язані з цим труднощі в економіці виникли не сьогодні, а накопичувались протягом тривалого часу. Суспільство стрімко розвивається, його потреби зростають, що вимагає додаткового використання природних ресурсів. Навколишнє природне середовище є унікальним та єдиним середовищем існування людини як біологічного виду. Але у світлі збільшення дестабілізуючих факторів, що впливають на стан природного середовища у світі (бурхливий науковотехнічний прогрес, збільшення населення Землі та потреб людства у ресурсах, деградація основних компонентів біосфери і зниження здатності природи до самовідновлення, збільшення екологічної шкоди від стихійних лих і техногенних катастроф) природні ресурси сьогодні як ніколи потребують раціонального управління та належної охорони на усіх рівнях управління.

Через стрімке зростання населення планети у XX ст вперше, виник дефіцит багатьох життєво необхідних ресурсів (питної води, їжі та ін.), деякі з яких вже у найближчому майбутньому можуть бути вичерпані повністю. Нині для нормальної життєдіяльності людства необхідно 14,1 млрд га, або 2,12 га на одну людину. Біологічні можливості нашої планети вже перевищені на 20 \%. За умови збереження існуючих тенденцій, за оцінками ООН, у 2030 р. потрібно буде на 50 \% більше їжі, води та енергії [22]. Тому, на якісно новий рівень виходить потреба в міжнародному захисті природних ресурсів, досягнення якого можливе лише 3 підписанням міжнародно-правових угод природоохоронного спрямування [23, с. $68]$.

Під раціональним (оптимальним) природокористуванням розуміють вивчення природних ресурсів, їх ощадлива експлуатація, охорона та відтворення 3 урахуванням не тільки нинішніх, але й майбутніх інтересів розвитку господарства країни та збереження здоров'я населення. Раціональне природокористування - це свідоме регулювання природогосподарчих зв'язків на економічній основі. Вони базуються на всебічному обліку й оцінці природних ресурсів, їх регулюванні і використанні в господарчому механізмі.

Поняття «раціональне природокористування» складається з трьох основних 
елементів - економічна ефективність використання, охорона і відтворення, представлені на рис. 1.

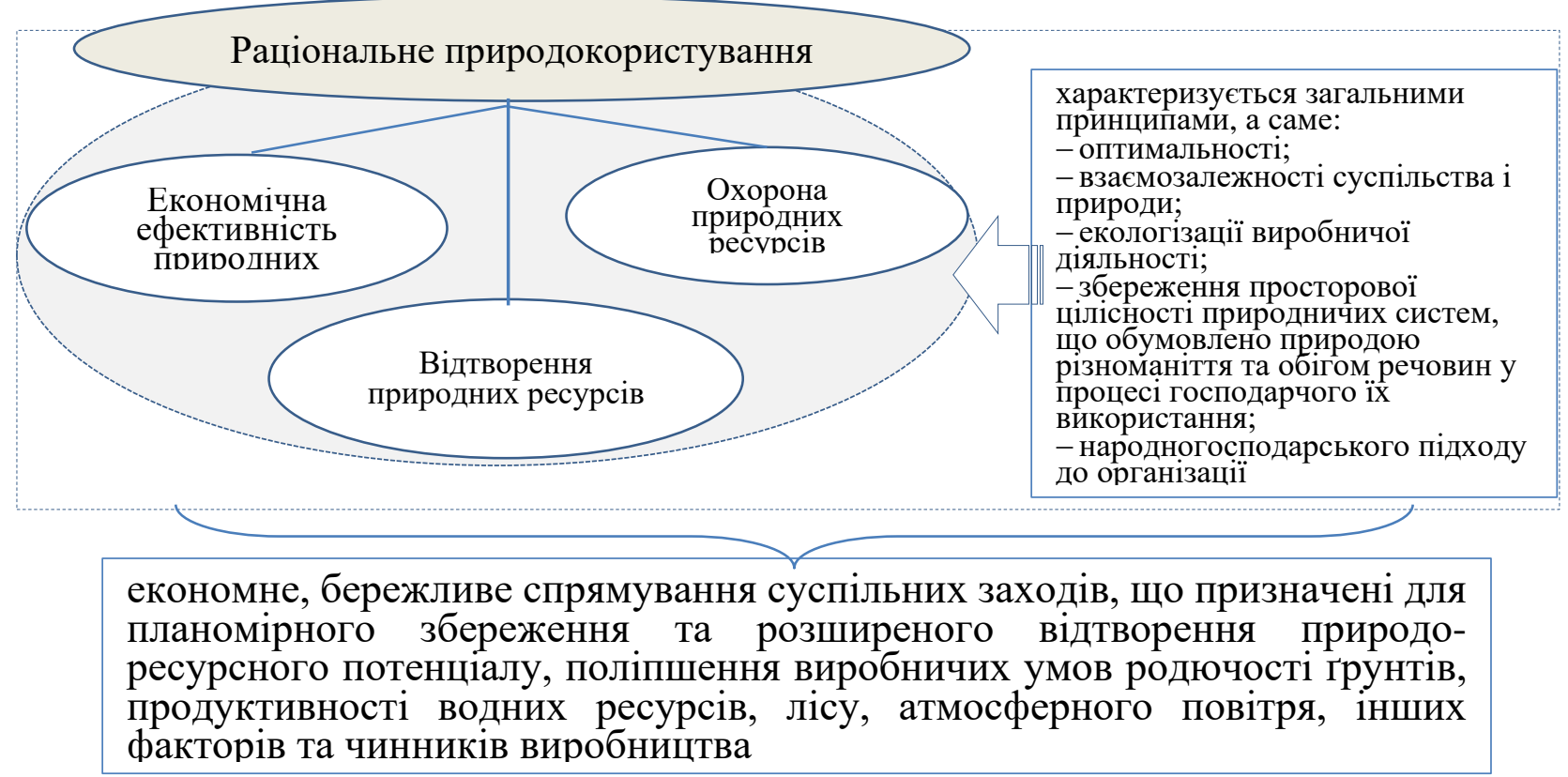

Рис. 1. Основні елементи раціонального природокористування

Економічна ефективність використання означає отримання максимальної кількості високоякісного продукту за умови мінімальних витрат на виробництво і економне витрачання самого ресурсу.

Найважливішим показником ефективності є вихід продукції на одиницю використаного ресурсу за умови визначеного рівня виробничих витрат.

Критеріями оцінки природоохоронних заходів є показники залучення ресурсів до господарчого обігу з цільовим призначенням, нормативи якості середовища та ресурсів, показники нормальної і фактичної продуктивності ресурсів, розміри збитку господарству країни, стан здоров’я населення.

Відтворення природних ресурсів означає відновлення обсягів експлуатованих ресурсів та їх запасів, відновлення втрачених властивостей i якості.

Критерії вирішення проблеми відтворення - це ступінь дефіцитності ресурсів і задоволення ресурсами потреб виробництва, а також стан екологічного оточення [22].

Кожна держава застосовує власні моделі управління природними ресурсами. Найбільш розвинені 3 них досягли значного успіху в природоохоронній сфері. Україна є надзвичайно багатою природними ресурсами 
країною, так наприклад, 3 60,3 млн. га загальної площі території 40 млн., покриває земля, придатна для сільськогосподарського використання [24, с. 1]. Проте, наша держава відносно нещодавно стала на шлях демократичних перетворень та євроінтеграційного вектору розвитку, з огляду на що, сьогодні як ніколи актуальним $є$ аналіз досвіду економічно розвинених країн світу, їх екологічних та економічних традицій управління природними ресурсами, та раціонального їх використання.

Концентрація світових ресурсів у досить обмеженому колі країн та суб’єктів призвела до високого рівня життя для однієї частини та бідності, без надії покращити своє становище, - для іншої, що підтверджують статистичні дані. Так, співвідношення між однією п’ятою найбільш заможною та одною п’ятою найбіднішою частинами населення Землі за останні сто років збільшилося з 3:1 до 75:1. У деяких країнах світу понад 90\% жителів має дохід менше 2 дол. у день. Близько 1 млрд людей постійно, а 2 млрд - періодично голодує [22].

У XXI ст. міжнародне співробітництво реалізується через Програму 3 охорони навколишнього середовища, Світового фонду дикої природи, Міжнародного союзу охорони природи. Міжнародні організації ЮНЕСКО, Всесвітня організація здоров’я, Продовольча i аграрна організація також розробили довгострокові програми зі взаємодії людини i навколишнього середовища. Механізмом якомога повнішого задоволення інтересів різних учасників природоохоронної діяльності стала деталізація загальних положень концепції сталого розвитку національними урядами на загальнодержавному, регіональному та місцевому рівнях.

У більшості економічно розвинених країн програма підтримки і покращення якості навколишнього середовища були прийняті ще наприкінці 60$\mathrm{x}$ - початку 70 x років минулого століття. Для організаційного забезпечення їх виконання в той же період були створені спеціальні установи [24, с. 37-45]. Завданням таких установ було розробка стандартів якості природного середовища, контроль за виконанням даних стандартів i в забезпеченні ефективного механізму впливу на підприємства - джерела шкідливого впливу на навколишнє середовище - у випадку порушення вказаних стандартів. В 
результаті діяльності природоохоронних організацій i розвитку науковотехнічного прогресу окремі держави покращили показники природоємності продукції, що вироблялася за рахунок енергозберігаючих технологій. Це підтверджується такими показниками, як енергоємність продукції і викиди вуглецю і сірки (табл. 1) [25].

\section{Показники природосмності продукції в країнах світу (на 1000 дол. США).}

\begin{tabular}{|l|c|c|c|}
\hline \multicolumn{1}{|c|}{ Країни } & $\begin{array}{c}\text { Енергоефективність, } \\
\text { т нафт. екв. }\end{array}$ & Викиди SО2, кг & Викиди Со, кг \\
\hline Японія & 0,17 & 0,3 & 0,42 \\
\hline Німеччина & 0,21 & 1,1 & 0,52 \\
\hline Франція & 0,21 & 0,9 & 0,31 \\
\hline Норвегія & 0,22 & 0,3 & 0,32 \\
\hline США & 0,28 & 2,3 & 0,72 \\
\hline Великобританія & 0,20 & 1,8 & 0.49 \\
\hline Канада & 0,36 & 4,1 & 0,73 \\
\hline Країни ОЕСР & 0,24 & 2,1 & 0,58 \\
\hline Росія & 0,61 & 6,0 & 1,54 \\
\hline
\end{tabular}

Прикладом законодавчого оформлення частини національної природоохоронної програми є Закон про чистоту атмосферного повітря, прийнятий Конгресом США в 1970 р. У відповідності до даного акту в 1971 р. у Сполучених Штатах були введені в дію стандарти з обмеження викидів у атмосферу сірчаних та азотних сполук при згоранні органічного палива. В 1977 p. Конгрес США ввів поправки у вказаний закон, що розділяв усі теплові електростанції США на дві категорії: побудовані до 1978 р., що не мають приладів для контролю за шкідливими викидами в атмосферу і побудовані після 1978 р., що мали такі прилади [26,с. 12-18].

Окрім того, у деяких штатах США функції управління охороною навколишнього середовища передано неспеціалізованим органам: місцевого планування, архітектури та будівництва, охорони здоров'я, комунального господарства, транспорту, поліції тощо. В інших утворені спеціальні підрозділи - департаменти охорони навколишнього середовища. Функції охорони навколишнього середовища за змістом неоднакові в різних муніципалітетах. У 
більшості випадків увагу звернено на раціональне використання й охорону земель, вод, атмосферного повітряного благоустрою та боротьбу із забрудненням територій твердими відходами [27, с. 40]. Окрім того, в багатьох штатах США знайшла підтримку концепція з використання спільних природних ресурсів.

Кожна держава учасниця ЄС створює адміністративний орган, повноваженням якого є здійснення реєстрації процесу випуску, утримання, передання, придбання моніторинг та скасування викидів. Так, наприклад у Німеччині адміністрування кількості викидів покладено на Федеральне агентство навколишнього середовища, у Бельгії такі функції виконує Національна кліматична комісія [28, с. 158]. Завдяки запровадженню даного ринкового механізму відбулося спонукання держав до впровадження енергоефективних енергозберігаючих технологій, що дозволило здійснювати торгівлю невикористаними квотами, тим самим поповнюючи державну казну.

Серед європейських країн, слід відмітити Швейцарію діє, яка реалізовує національну політику охорони довкілля через закони, договори, ринкові механізми, природоохоронні інвестиції, кооперацію державних та приватних структур, освіту та пропаганду. Національна природоохоронна політика $\epsilon$ невід’ємною складовою державних та приватних планів розвитку, і іiі виконання забезпечується 3 боку як державних структур (депутатами, міністерством, поліцією), так і приватних - Лігою охорони природи, а також численними екологічними бюро, постійними змішаними комісіями 3 представників державних урядовців та членів приватних організацій [29, с.48].

Найбільшими досягненнями у сфері природоохоронних заходів на території Східної Свропи відзначила Польща. Польща запроваджує широкий ряд екологічних ініціатив та концепцій. Створюються фінансові інститути, що надають можливість ефективного фінансування охорони природи, до них відносяться наступні джерела: державний бюджет. Даний фонд формується конкретно 3 податків на забруднення та відновлення природних ресурсів, найбільш важливого джерела фінансування охорони природи; екологічні фонди, національні парки, вітчизняні та міжнародні недержавні організації тощо. Більш того, після вступу країни в Свропейський Союз за рахунок великої кількості 
спеціальних фондів фінансування охорони природи значення державного бюджету в зазначеній сфері відійшло на другий план.

Ефективною формою фінансування, зокрема $є$ міжнародна фінансова допомога, яка надається для скорочення викидів сірки та окису азоту з території Польщі, зменшення забруднення Балтійського моря, скорочення викидів газів i забруднювачів, що викликають пошкодження озонового шару Землі, охорона біорізноманіття [30].

Природоохоронне законодавство різних країн розвивається схожим чином. Відмінності породжує лише різне національне розуміння проблем охорони навколишнього середовища, пріоритетів у здійсненні природоохоронної політики, національно-історичних традицій та інших факторів. Сучасна екологічна політика в зарубіжних країнах ефективна тому, що базується на історично сформованій системі фінансовоекономічних і правових регуляторів, існуючих високих економічних можливостях. Крім того, слід відмітити істотне підвищення за останні десятиліття екологічної культури населення Свропи, США, Японії та ряду інших держав, зокрема через розуміння необхідності економічного розвитку в якісно іншому, природоощадливому напрямку.

Нажаль, сучасний стан природокористування може бути охарактеризований як нераціональний, бо він призводить до виснаження (іноді до зникнення) природних ресурсів, навіть таких, що відновлюються, до посилення забруднення навколишнього середовища. Причин таких явищ достатньо. Насамперед це недостатнє знання законів екології, дуже слабка матеріальна зацікавленість виробників продукції, низька екологічна культура населення, нехтування прямою залежністю екологічного стану країни 3 економічним та ін.

Проаналізований міжнародний досвід управління природоохоронною сферою вказує на необхідність здійснення гармонійного об’єднання зусиль у діяльності інститутів громадянського суспільства та природоохоронних органів державної влади. При цьому розвиток громадянського суспільства ні в якому разі не повинен здійснюватися за рахунок послаблення держави або відсторонення від виконання покладених на неї функцій у галузі охорони навколишнього середовища, природокористування та забезпечення екологічної безпеки. 
Основними напрямами поліпшення ефективності у сфері охорони навколишнього середовища в Україні є децентралізація влади, тобто передача широкої кількості природоохоронних повноважень органам муніципальної влади, формування системи екологічного виховання, мотивація молоді, віднайдення нових економічних стимулів для виробників для запобігання забруднення природного середовища, через запровадження системи вигідного кредитування, пільг тощо. 